\title{
STUDENT MICRO LOAN MANAGEMENT SYSTEM
}

\author{
Jay Chaudhari \\ Department of Computer Engineering \\ Mumbai University, Mumbai, Maharashtra, India \\ Vinay Shirole \\ Department of Computer Engineering \\ Mumbai University, Mumbai, Maharashtra, India
}

\begin{abstract}
In the daily transmuting scenarios of the financial world, lenders and students are searching for new, modern and digital techniques to manage their loans through an automated management system that can ease their effort. The need of this system is to make the process flexible, scalable, agile and fast while being more affordable and reliable.
\end{abstract}

Student Micro Loan Management System is an application which will provide users information with different types of loan available for students. This application gains the headway of an understudy and moneylender simple in giving the confirmed data about student micro loan. This project provides the information about various details of Student micro (Tuition and facilities) loans which are allocated for students. This task accumulates all the data of the advances. This project provides the information about various details of education loans and makes it available to users in user-friendly website/app.

Keywords - Microloans, Lender, Non-profit, Web Application, Student, EMI.

\section{INTRODUCTION}

Finance is one of the key factors that is needed in our day-today life. It has come to an expanse that people cannot live without financial loans in this world. The bank and the financial institution come with the new financial product on the day-to-day basis. In order to market this product, there should be some application that is necessary. So, this application will be of great help. As the name suggests, this application provides student micro loan from verified sources for student without interest as non-profit application.

\author{
Aditya Agarkhed \\ Department of Computer Engineering \\ Mumbai University, Mumbai, Maharashtra, India \\ Prof. Pramila Mate \\ Department of Computer Engineering \\ Mumbai University, Mumbai, Maharashtra, India
}

\section{A. Traditional System -}

Education loan may be a special purpose loan given by banks and financial institutions to hide the value of any higher degrees or specialized courses. The education loan provided by banks in India cover the fees Payable to the College. It additionally covers the assessment charge, inn expense, library expense, lab expenses, alert stores, refundable store. Building reserve upheld by Institution bills or receipts, Purchase of Books, gear, instruments, outfits, Travel costs/entry cash for concentrates abroad, acquisition of PCs - fundamental for fruition of the course and the other cost needed to complete the course - like investigation visits, project work, postulation, and so on

The increasing expense of advanced education has become a colossal reason for stress for students. How might one be prepared to subsidize the cost needed for proficient courses is the great worry for individuals looking to expand their capabilities. On the off chance that an understudy is trying to travel abroad for seeking after higher investigations, the spreads are far more prominent when contrasted with concentrating in India. Instruction credit to pay for the high educational expenses and other related expenses is quick turning into a prerequisite for an eager understudy. Banks give incredible monetary assistance expected to cover practically every one of the costs brought about for a fruitful fulfilment of the predetermined course.

\section{B. Web Application -}

Advance handling right away gives upper hand and better usage of time for the candidates. Henceforth, there is need to have an innovation that is efficient for the moneylenders and advantageous for student. Commonly, the borrowers need to manage measure delays because of the manual advance handling framework, which at times, brings about losing their forthcoming clients through and through. A very much planned and adaptable Student credit the executive's 


\section{International Journal of Engineering Applied Sciences and Technology, 2021 \\ Vol. 5, Issue 12, ISSN No. 2455-2143, Pages 84-87 \\ Published Online April 2021 in IJEAST (http://www.ijeast.com)}

framework expects to improve the quality, turnaround time, and administration for end-clients.

They guarantee that the credit suppliers are better prepared, proficient, and spry. All in all, they empower improved client experience. It assists the student with getting every one of the offices regardless of whether their family pay can't manage the cost of the instruction required. Application has reasonable and appropriate terms and conditions so student from each classification can apply for credit. The point of the application is to help and energize the student.

It is applicable to each and every student who fulfills the criteria. Web App objectives are-

\section{Broader Coverage}

\section{User Friendly}

3. Speed and Agility

4. Security

\section{Customer Service Support.}

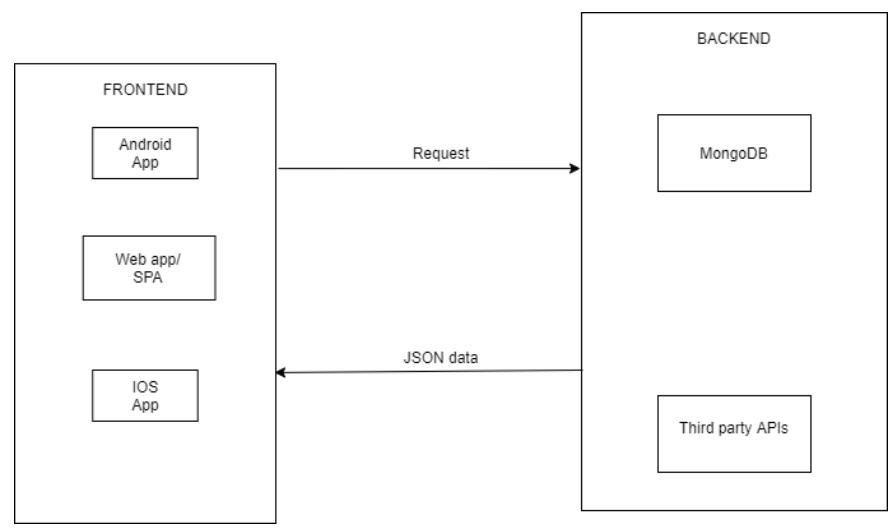

Fig. 1. Architecture Diagram

\section{LITERATURE SURVEY}

From most recent couple of years, the businesses and banking area utilizing on the web the executives' frameworks for all credits and store work. Yet, for government associations and student helping non-administrative associations (NGO) which fills in as non-benefit have disconnected framework which makes it hard to record and deal with all work. Just as individuals who needs to help student and don't believe the association can likewise interface utilizing our web application which will give stage to think about financing costs and absolute time-frame of the advance of different banks, with the goal that the student can choose the best subsequent to acquiring all the information on the accessible alternatives in the business. It will likewise give insights concerning outsider loan specialists that will give limited quantity of cash to student with certain pace of revenue.

\section{A. Limitations -}

\section{a. Eligibility Criteria -}

Banks give education loans only to the students who comes under their criteria and whom they consider deserving. There are certain other eligibility criteria for the loan and it varies from bank to other financial institutions.

\section{b. Repayment pressure -}

Once you have availed the loan, there is always the pressure of repayment. As you all know, the loan taken has to be paid and also to be paid as installments for given time period. So, there is a repay pressure on the students with time bounding and also to study as well.

\section{c. Offline Methodologies -}

All the loan processing procedure is done through offline modes.

\section{PROPOSED SYSTEM}

In the proposed system student will do the request with using our web app platform. student should fill and upload all the required details for verification to be done by admin. Then connection will be established with database of the current lenders and information related to students will get displayed on the application of lender after lenders decision further process of money lending will proceed. With all EMI payment details as per needed.

\section{A. Methodology -}

The task will be a full Stack project and give functionalities like User Authentication, installment door and contact support. Different parts like home, about us, student, banks, associate with us and logout are given to client. There will likewise be three kinds of clients i.e., student, banks and outsider moneylenders. In Student segment, we will have insights regarding various projects for which the advance is conceded and their particular measures. In Bank segment, insights concerning different banks and their separate arrangements to concede the credit will be displayed. It will have all the data about the bank side. Reach us area will have structure to submit. Upon accommodation client will be reached and clarified the subtleties face to face. Different modules of the task will likewise permit the utilization to transfer the reports as pdf or pictures with the end goal of credit endorsement. This approval will bring about the endorsement of conclusive constraint of the arrangement sum. Student profiles will be made to know every one of the subtleties of the student with respect to the credit residency, the interest and the last conclusion sum. The client can likewise think about the instruction credit measure and the insights concerning applying for advance.

\section{B. Data Model -}

The System's database consists of following tables: 


\section{International Journal of Engineering Applied Sciences and Technology, 2021 \\ Vol. 5, Issue 12, ISSN No. 2455-2143, Pages 84-87 \\ Published Online April 2021 in IJEAST (http://www.ijeast.com)}

a. Admin: This table will have information about admin id, admin name, address, service number.

b. Installments: It provides detail information about installment id, loan id, amount, is paid amount, payment date.

c. Loan details: This table maintains information about loan details id, student id, lender id, loan date, duration, etc.

d. student: This table maintain details of student id, name, college id, documents, verified status, profile image, etc.

e. Lender: It Provides details of lender id, name, address, verified status, profile image, etc.

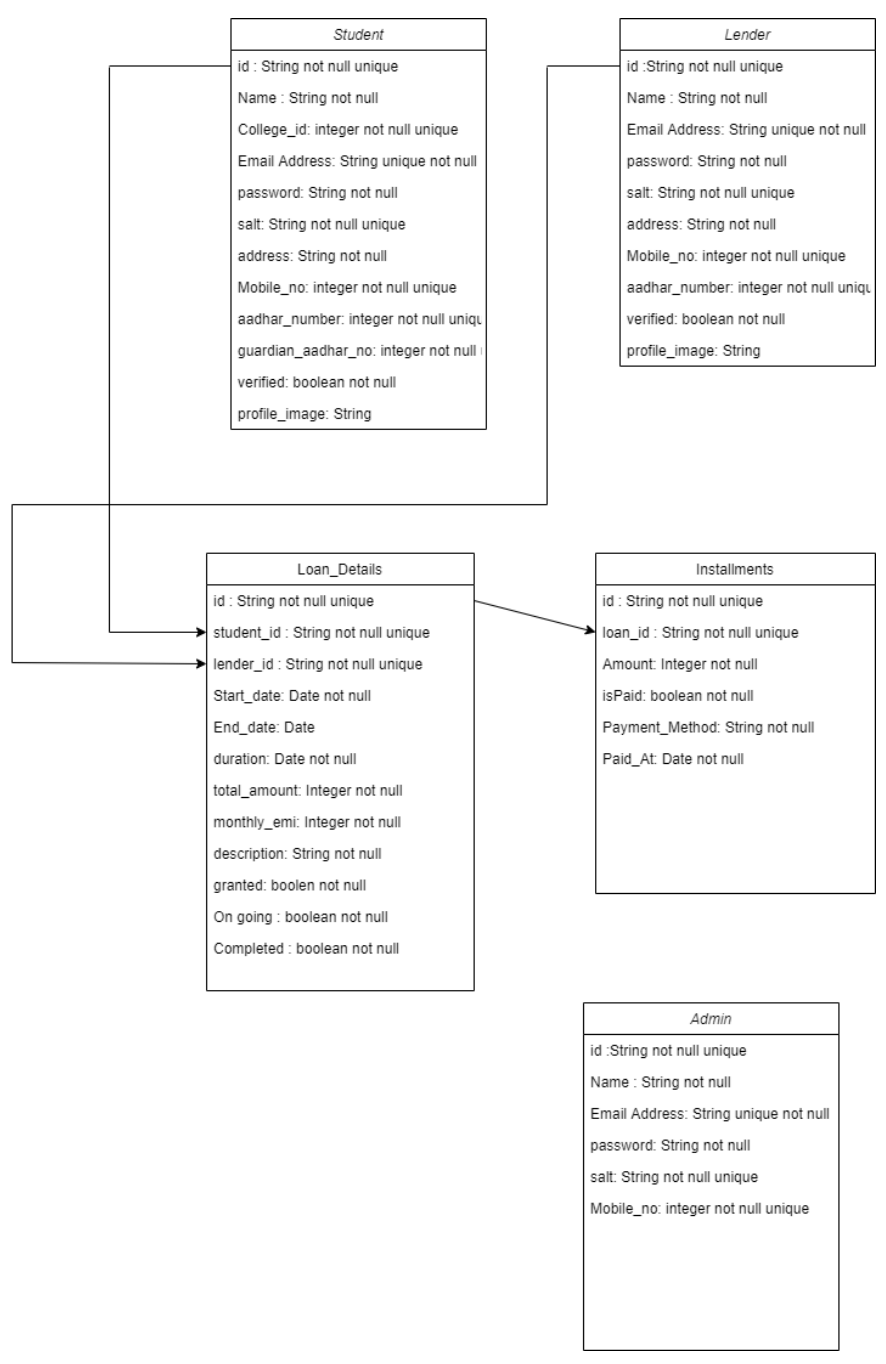

Fig. 2. Schema of database

\section{IMPLEMENTATION DETAILS}

\section{A. Web Application Features -}

Student Microloan Management system has following features:
a. Reduces loan process time
b. Maintain record of every activity
c. provides verifies sources and details of users.

B. Technologies used -

a. Hardware Requirements:

i. Hardware CPU; Operating system independent

ii. Memory: 2GB, x86-64 (64 bit)

iii. Mouse Microsoft or compatible

iv. HDD $200 \mathrm{MB}$ (No local dataset)

b. Software Requirements:

i. Windows 7 (32-bit or 64-bit) and above OS

c. Browser:
i. Google Chrome
ii. Microsoft Edge

\section{Micro LoAN}

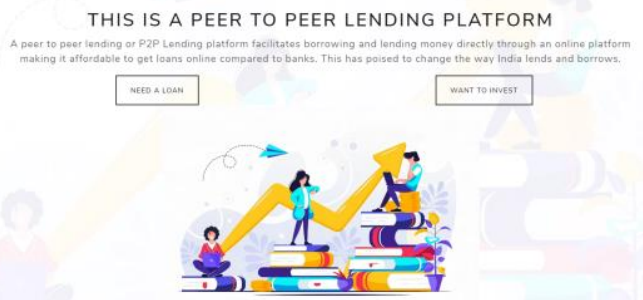

Fig. 3. Architecture Diagram

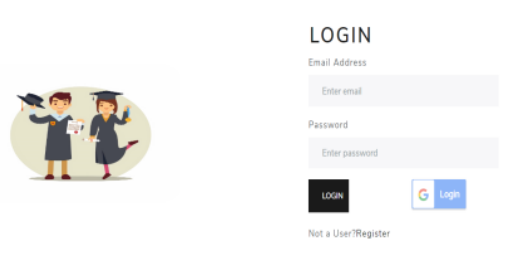

Fig. 4. Architecture Diagram

Fig. 5. Architecture Diagram 


\section{International Journal of Engineering Applied Sciences and Technology, 2021 \\ Vol. 5, Issue 12, ISSN No. 2455-2143, Pages 84-87 \\ Published Online April 2021 in IJEAST (http://www.ijeast.com)}

\section{CONCLUSION}

This task can carry us to a decision that a framework can give miniature advances to student to a specific measure of time and lessen the heap over banks that give credits for a bigger scope. These miniature advances depend on the student needs and can be satisfied by outsider loan specialists. Any student can apply for the credit the extent that the student is qualified for the base standards that will be satisfied. This framework will permit the student to deal with their credits in a simpler design instead of the monotonous old techniques. The loan specialist will likewise savor the highlights of the framework by dealing with his side of the interaction.

\section{REFERENCES}

[1] Mtaki Frank, Dr. B. Ganesh, May 2016 Loan Management and Risk Practices in Banks Vol -4, Issue 5 on, $(\operatorname{Pg} 175-184)$.

[2] Mishra Nandita, Chandra Munesh, Oct 2010 Microfinance in Indian Banking Industry and Its Future on (Pg625-628).

[3] Bandyopadhyay Arindam, July 2016, Studying borrower level risk characteristics of education loan in India on (Pg127-135).

[4] Mohd Sharif, Oct 2018, A Study on the Performance of Microfinance Institutions in India by, International Academic Journal of Accounting and Financial Management Vol. 5, No. 4, 2018, pp. 116-128

[5] Shastri Rajesh, April 2009, Micro finance and poverty reduction in India (A comparative study with Asian Countries), Vol.3 (4), pp. 136-140.

[6] Dr Sharma Swati, April 2018, Growth of Micro Finance in India: A Descriptive Study, Vol.7(2):20-31, DOI:10.24105/gjiss.7.2.1804 on (Pg20-31).

[7] Khanwalker Sandeep, January 2019, Education Loan in India - A Review Vol. 7 (1):48-55 (Pg49-55).

[8] McKernan, (2002), The Impact of Micro-Credit Porgramme on Self-Employment Profits: Do NonCredit Program Aspect Matter?e, The Review of Economics and Statistics, 84(1):93-115.(Page93-115)

[9] Conning, J., (1999), Outreach, Sustainability, and Leverage in Monitored and Peer-Monitored Lending, Journal of Development Economics, Vol.60, No.1, pp.51-77.
[10] Ghosh, Jayati (2013), „Microfinance and the Challenge of Financial Inclusion for Developmente, Cambridge Journal of Economics, Vol. 37 (6):1203-1219.

[11] McKernan, S.M. (2002), „The Impact of Micro-Credit Porgramme on Self-Employment Profits: Do NonCredit Program Aspect Matter? ${ }^{\text {ee }}$, The Review of Economics and Statistics, 84(1): 93-115.

[12] Wydick, B., 2001, Group Lending under Dynamic Incentives as a Borrower Discipline Device, Review of Development Economics, Vol. 5, Issue 3, pp. 406-420

[13] Knapp, L. G., Seaks, T. G. (1992). An analysis of the probability of loan default on federally guaranteed student loans. The Review of Economics and Statistics, 74(3), (Page404-411). 